\title{
The value of information in South Africa's new democracy
}

\author{
Genevieve Hart and Mary Nassimbeni
}

\section{Introduction}

In this paper, we trace the link between information and democracy through an analysis of the current approach of a new democratic government in South Africa which succeeded a government whose foundational philosophy was the denial of freedoms to the majority and the entrenchment of privilege for the white minority. In this analysis, we uncover continuities and discontinuities and account for the flux and policy drift with respect to the freedom of information manifest in the two regimes. We examine the famous quotation attributed to Thomas Jefferson that "Information is the currency of democracy" and explore the extent to which, in spite of its longevity, the claim is applicable today in contemporary South Africa. Thus we question what the consequences are when people are excluded from the possibility of enjoying the currency in a proclaimed democracy and also what the effects on democracy are of a debased currency, manifest, for example, in misinformation and overregulation of access to information. We surface evidence of these paradoxes in our examination of the sort of democracy South Africans now enjoy and how information policies and practices impact on its full expression - not only through universal suffrage but also in active citizenry. We conclude by reflecting on how libraries promote deliberative democracy and can disrupt the dominance of entrenched knowledge systems that marginalise the local and indigenous.

\section{The state's stranglehold on information in the pre-democratic state}

The pre-democratic regime was marked by brutal oppression of people and the suppression and distortion of information which took effect in a network of legislation designed to assert and entrench the privilege of the white minority and to subjugate the black majority, while at the same promoting the fiction internally and externally that it upheld democracy. The main pieces of legislation (Legal veneer, 2013) relating to the theme of this paper are:

- Population Registration Act No. 30 of 1950 (1950) the fundamental piece of legislation that distributed privilege, and withheld basic rights according to "race". From this cornerstone legislation arose a number of security and other laws which disempowered people and hindered the free flow of information, for example.

- The Bantu Education Act of 1953 whose philosophy was based on inferior educational provision for people other than white. 
- The Unlawful Organisations Act of 1960, which banned the liberation movements of the African National Congress (ANC) and the Pan Africanist Congress (PAC).

- $\quad$ The Publications Act of 1974 which could ban specific titles (1976).

- Internal Security Act of 1984, which had far-reaching powers to block, control or threaten political expression.

According to the South African born author Christopher Hope (1976), the control required by the philosophy of apartheid meant that government presided over "every activity from bowel movements to burials" (p. 95). He himself experienced the crippling restrictions on free speech when he went into exile to England after his poems were banned in 1976. In an interview in 2006 he observed: "Things have emphatically changed for the better but I see old patterns repeating" ( Jaggi, 2006).

Christopher Merrett (2001) gives a comprehensive description of the legislation enforcing official secrecy and the control of information flow. He points out that state security officials sent in 95 per cent of the 23,435 titles submitted to the Publications Board under the censorship laws. The public, for whose ostensible moral protection the law was enacted, submitted only 5 per cent.

In its years of being in exile, the African National Congress Conference (ANC) the liberation movement that became the new government in 1994, had understood and used to good effect the power of information by documenting the brutality of the government and raising support for its liberation struggle. Their strategy led also to the creation of alternative information networks, thus effectively bypassing the restrictive legislation that banned persons, their utterances and publications. Thus the 1980 s saw the establishment of a number of alternative community-based structures, e.g. resource centres (which acted in parallel to conventional public library structures), legal clinics and other organisations, that "increasingly marginalised and replaced official governmental organisations" (Kurtz, 2010). Academic libraries played an important role in preserving the archives of many of the anti-apartheid structures by receiving and curating their collections (Harris, 2002). The established professional body, the South African Institute for Library and Information Science, however, did not protest against the abuses of human rights, such as the exclusion of black people from public libraries in "white" areas. In reaction, a small group of progressive librarians formed an association, the Library and Information Workers Organisation, to take on issues of social justice (Merrett, 2004). Dick cites other instances of resistance to the restrictions on the free flow of information in libraries, when some public librarians flouted the law to allow access to "white" libraries and some others secretly used their space and resources for the political education of youth engaged in the struggle against apartheid (for example through the subterfuge of chess clubs) (Dick, n.d.).

\section{Information flow in the early days of democracy}

The year 1994 brought a break with a system of government that ruled by fear, secrecy and oppression, ushering in a new democratic dispensation, with the election of the ANC to power. The new democracy expressed its foundational principles in the Constitution of 1996 - universally hailed for its progressiveness - which enshrines the many freedoms of 
South African citizens including universal suffrage and the freedom of information. Section 32(1) of the South African Constitution guarantees everybody "the right of access to any information held by the state and any information that is held by another person and that is required for the exercise or protection of any rights". The new government then had to start to dismantle the legislation of previous decades inimical to the constitutional values and to enact new legislation to give effect to the new freedoms. At the same time, it started the task of building a new nation and taking steps to heal the fractures of the past. One of its earliest pieces of legislation to this effect was the National Unity and Reconciliation Act of 1995 which established the Truth and Reconciliation Commission (TRC), "to help deal with [the violence and human rights abuses from all sides that] happened under apartheid" (Truth and Reconciliation Commission n.d.). It conducted its work through a series of public hearings, starting in April 1996. The full archives of the TRC are being assembled by the South African History Archive (SAHA) and the University of the Witwatersrand so that the public may have free access to a complete set of records (TRC Collections, n.d.). The reason for the piecemeal and onerous construction of this shadow archive is that, while the official TRC records were released to the National Archives by law, they are not freely available online, their use being governed by the granting of individual permissions on application to the Department of Justice, their effective custodian. Moreover, not all files have been deposited with the National Archives. For example, the transcripts of hearings held behind closed doors were not released and were only secured for the SAHA Archive after a successful legal process in terms of the Promotion of Access to Information Act (PAIA) to compel the Department of Justice to release them (Davis, 2015). We discuss the PAIA Act in greater detail in a section below. While the TRC generated a massive volume of information relating to its remit, it revealed that " that all the records confiscated by the security police from individuals and organisations opposed to apartheid were destroyed before the 1994 General Election" (Harris, 2002).

Another aspect of reconciliation that the new government had to address was the governing of a people who had been separated by law and geography. Many of the people living in rural areas were governed by a system of traditional law which embraced "the adherence to indigenous customs and modes of living", while an increasing number of urbanised people were accustomed to a "modern" life enjoying "contemporary modes of living and production based on (Western) industrialisation" (Hagg and Himonga, 2014, p. 106). The constitution recognises traditional law and its institutions, and government tries to hold in equilibrium these rights and those associated with a contemporary democracy (Hagg and Himonga, 2014, p. 106). Thus, non-elected traditional leaders (referred to popularly as "chiefs" in governance structures, are given a voice through the House of Traditional Leaders.

By 2000, South Africa had all the accepted ingredients of an open democracy: a progressive constitution, guaranteeing freedom of information and of expression; free elections; a multiparty parliamentary system, allowing for parliamentary oversight of the executive; an independent judiciary; six Chapter 9 institutions charged with guarding the 
constitutional democracy, like the Public Protector. The PAIA of 2000 (aka Open Democracy Act) promised to secure government transparency and accountability.

\section{Consolidating democracy post 2000}

The Human Science Research Council's (HSRC) 2000 review of governance since 1994 was optimistic, with Houston and Muthien (2000) asserting "the new South Africa augurs well in terms of formal democracy, i.e. the key pillars of democratic consolidation are in place" (p. 63). However, they warned that effective participatory democracy would require two things: an "informed public and a vibrant civil society" (p. 64). Events in the years since have certainly borne out the validity of their warning.

Concerns over the consolidation of the young democracy were evident by 2010. Voter turnout declined in the 2004, 2009 and 2014 national elections, with 40.66 per cent of eligible voters choosing to vote in 2014 compared with 58 per cent in 2004, 64 per cent in 1999, and 85 per cent in 1994 (Talbot, 2004; McKinley, 2017, p. 121). "Disinterest and disillusionment" are the reasons most commonly given for the decision to abstain (Struwig et al., 2016, p. 149). The disinterest is disproportionately strong among South African youth, which has disproportionately high unemployment and poverty (Ranchod, 2016, p. 119).

Of course, the percentage of voters compares favourably with many established democracies in the West; and, arguably, the decline in voters might be due to the fading of the first flush of excitement at the demise of apartheid. But democracies depend on more than elections. According to Davids's analysis of the HSRC's 2004-2006 social attitudes surveys, South Africa was far from participatory democracy (Davids, 2010, pp. 71-80). More than half of the respondents across the three surveys, for example, reported that:

- $\quad$ politics was too complicated to understand;

- they did not know who their ward councillors were;

- $\quad$ politicians could not be trusted to "to do the right thing" (p. 71); and

- their local governments took too many decisions in secret.

Davids (2010) warned that, if South Africans continued to doubt democracy's power to improve their lives, they would resort to "protest politics" (p. 86). The analysis of subsequent HSRC social attitudes surveys lend support to his warning (Struwig et al., 2016, p. 151). By 2014 violent service delivery protests had increased by 28 per cent per year (Calland, 2013b, p. 419). Ominously, declines in approval of the present government seem to match declines in support for democracy. Thus, the 2015 Afrobarometer public attitude survey on democracy and governance concluded that "a majority of citizens are willing to give up regular elections in favour of basic service provision” (Lekalake, 2017, p. 1).

\section{An informed public}

The importance of the right of access to information in South Africa's new democracy lies in its potential force in the redistribution of power, as argued in the LIS Transformation Charter:

The point of establishing the right of access to information is to try to rebalance the power relationship, and to produce long-term, reliable structures that will remove the need for 
dependence in the future. That, at least, is the hope that underpins the Charter, and that is why the right of access to information is worth pressing for. (Library and Information Services Transformation Charter, 2014: viii-ix)

Houston and Muthien's (2000) warning on the on-going need for an "informed public"(p. 64) to consolidate and sustain the new democracy has three dimensions. The first is the "information poverty" that comes from the generally inadequate access to the infrastructure and technologies needed to access information, like libraries and the internet (Britz, 2004). Some years ago, Castells (1998) warned of the dangers of an alienated "fourth world", claiming that the network society is "intertwined with rising inequality and social exclusion throughout the world" (p. 69). South Africa's National Development Plan (NDP) promises to bridge the information infrastructural gaps in its vision of a "dynamic and connected information society and a vibrant knowledge economy that is inclusive and prosperous" (National Planning Commission, 2012, p. 190). Acting on the NDP's promise that every community will have a "local library filled with a wealth of knowledge" (p. 15), National Treasury has allocated billions of rands since 2008 to the building of new public libraries in underserved communities (National Library of South Africa, 2016). And, the broadband policy of 2013, South Africa Connect, sets out targets for speedy broadband access aiming at 100 per cent coverage by 2030 (Electronic Communications Act, 2005, 2013).

The second dimension to "being informed" is information literacy: an open democracy requires citizens with the capacity to seek out information, assess its value, and use it to make decisions. Information literacy education has to accompany the provision of physical information infrastructure and is what, according to the HSRC survey of public access to ICTs in South Africa, distinguishes the work of public libraries from other services (Tlabela, Roodt and Paterson, 2007, p. 100). The recent evidence of undercover disinformation campaigns (e.g. Neate, 2017) highlights the need for information savviness and will be returned to below.

The links between these two dimensions of an informed citizenry and socio-economic development are widely accepted. Access to information is, after all, a lever or instrument of other economic, social and cultural rights (MckInley, 2004, p. 1; Adeleke, 2013, p. 100; Calland, 2013a, p. 18). Gumede (2011) of the Development Bank of South Africa asserts, "Democracy is not only compatible with growth and poverty reduction but may actually be crucial to both" (p. 1).

\section{Freedom of information post 2000}

The third dimension to the concept of an informed public is the control of information by the State. PAIA 2000 was hailed as a "gold standard" (McKinley, 2004) and "globally unique" (February and Pienaar, 2014, p. 41). However, quite soon, concerns surfaced over its half-hearted implementation by government and the private sector. Thus, in 2013 only 16 per cent of requests to government departments were successful and only 10 per cent of those to the private sector (McKinley, 2017, p. 111). McKinley (2017) attributes the 
problems to poor management of public records and "the ANC's state's general indifference"(p.111).

In the last few years, this "indifference" seemingly has shifted towards more active undermining of the right of access to information. Two pieces of security legislation are cited as evidence of increasing securitisation since 2009: the National Key Points Act of 1980 and the so-called Secrecy Bill. The National Key Points Act is a relic of the apartheid era's security measures against liberation movements. Ironically, its usage has increased under the ANC government - by 50 per cent from 2007 until 2012 (Right2Know, 2013). The most controversial application of the legislation came in 2013 when the then Minister of Public Works cited the Act in his refusal to release a forensic report on illegal expenditure at the President's private residence (Dimba, 2014, p. 87).

The Protection of State Information Bill (aka the Secrecy Bill) is reminiscent of apartheid security legislation, as the Library and Information Association of South Africa (2011) points out:

[...] excessive secrecy, classification and censorship of information are inherently antidemocratic and distinct reminders of pre-1994 politics [...]. Amongst other concerns, we wish to stress the danger inherent in this Bill whereby State documents, which form part of our cultural heritage, could be strictly classified or secretly destroyed, thus permanently removing important information from public access.

The motivation for the Bill was that it would tackle the perceived increase in information "peddling" (Mtshali, 2007). After the first version was withdrawn after huge public opposition, the later version was passed by Parliament in 2013, but has not been finally approved amidst doubts that it would not pass constitutional challenges (Dimba, 2014, p. 87). It would allow all 140 organs of state to withhold information on "highly subjective and potentially unconstitutional grounds" (IDASA, 2010) and would criminalise subjective and whistle-blowers and investigative journalists. The Bill is one sign of a "creeping authoritarianism" (McKaiser, 2017). Thus, echoing apartheid era rhetoric, state security officials routinely accuse open democracy advocates, like the Right2Know campaigners, of being "foreign agents" (Calland, 2013b, p. 134; Gqirana, 2016).

\section{Disinformation and "state capture"}

Recent revelations of disinformation campaigns on social media platforms, which cynically set out to exploit the vulnerabilities of the young democracy, have highlighted the need for the information savviness referred to earlier. Chapter 10 of the constitution lays out the principles of transparency in public administration, stating it must be "fostered by providing the public with timely, accessible and accurate information". Growing mounds of evidence of a "toxic nexus between money and politics" (Calland, 2013b, p. 425) show how far the present government has strayed from these principles. 
In 2016, the Public Protector released a report of its investigation into what has become generally known as "state capture" by a family close to the President, the Guptas. As Jacob Zuma rose to power, they allegedly cultivated their connections with his family by offering financial support and jobs (BBC News, 2016). By 2013, they themselves had so much power that they were able, for example, to bypass tendering procedures to illegally win lucrative contracts from state-owned enterprises (Comrie, 2017; Brummer and Sole, 2016) and offer government cabinet appointments ( Jonas, 2016). A judicial commission of enquiry is to be appointed but, in the meantime, the Amabhungane Centre for Investigative Journalism (2016-2017) has provided a trail of over 100, ooo leaked e-mails since 2010, which provide irrefutable evidence of the capture (Amabhungane and Scorpio, 2016-2017). The South African Council of Churches (2017) has provided confirming evidence from inside government of the systematic "siphoning of the assets of the State" by "a power-elite that is pivoted around the President of the Republic" (p. 6). Moreover, the State Capacity Research Project (2017), comprising academics across South Africa, has recently published a report under the telling title Betrayal of the Promise, which traces the clandestine workings since 2009 of a "shadow state" ( p. 6). Its tentacles have reached deeply into the South African Government, state-owned enterprises and the country's security apparatus in what the academics call a "de facto silent coup" (State Capacity Research Project, 2017, p. 3).

Earlier this year, the South African Communist Party (2017) published their research in the disinformation campaign orchestrated by the British public relations company Bell Pottinger on behalf of the Gupta family and its company Oakbay. The campaign, using fake Twitter accounts, was designed to divert attention from the Public Protector's report on state capture. According to one leaked e-mail to the President's son, an Oakbay employee, Bell Pottinger promised to "market a narrative that grabs the attention of the grassroots population who must identify with it, connect with it and feel united by it" (Thamm, 2017). The refrain chosen for the populist narrative was "white monopoly capital" or WMC; and indeed WMC has become the rallying cry of supporters of the President and militant groups like the Black First Land First (BFLF). Their online threats have escalated to violent disruption of public meetings, resulting in a judicial indictment against them (Uncensored, 2017).

Clearly, with 55 per cent of South Africans below the poverty line (Statistics South Africa, 2017, pp. 14-20), no one can deny the reality of "economic apartheid". There is wide agreement that radical economic transformation should have accompanied the political transformation in 1994. In 2012, the NDP, for example, repeated the ANC's warning at the birth of democracy that the high levels of poverty could threaten its future:

"No political democracy can survive and flourish if the mass of our people remain in poverty, without land, without tangible prospects for a better life" (National Planning Commission, 2012, p. 24).

As the journalist Marianne Thamm (2017) points out, it is repugnant that foreign private interests have made billions from stoking racial tensions. While denying culpability, in 
recent weeks, Bell Pottinger has reportedly cut its ties with Oakbay and has issued an apology for the "inappropriate and offensive campaign" (James, 2017).

\section{Threats to freedom of the press}

Section 16 of the constitution spells out the right to freedom of expression, excluding "advocacy of hatred that is based on race, ethnicity, gender or religion [...]". The previous section has provided examples of the watchdog role of the press in recent years and has alluded to the violent backlash from movements like BFLF. Researchers have documented the increasing levels of intimidation of journalists since 2011 (Barker and Hawkins, 2015, pp. 36-43). Press Ombudsman Joe Thloloe (2017) has cautioned against the state's "tinkering" with media freedom through the proposed statutory Media Appeals Tribunal (MAT). Thloloe (2017), who was imprisoned in 1977 under the Prevention of Terrorism Act, reminds of the censorship in the apartheid era, saying: "It's these ugly memories that stoke my passion for freedom of expression [...]. We should never again have to use the fig leaf of "I didn't know".

The MAT proposal first surfaced at the ANC's conference in 2007, amidst accusations that the existing self-regulatory mechanisms, like the Press Council of South Africa, were ineffective in regulating what the ANC Youth League (2010) called "spiteful and dodgy" newspapers. In response to this kind of criticism, in 2015 the Media Policy and Democracy Project undertook an investigation into the Press Council to examine the accusations (Reid and Isaacs, 2015). Its analysis of cases over a five-year period from 2009 found no evidence of bias and suggested that much of the suspicion of the print media comes from a conflation of the issues of transformation and diversity with those of post-publication accountability. They point out that the council cannot be held responsible for newspaper ownership patterns or for the lack of diverse content (p. 81).

The launch of The New Age newspaper in 2010 by TNS Media, owned largely by the Gupta family, promised to bring more balance. According to its Facebook pages, its vision is "to celebrate the achievements of a united South Africa" (www.facebook.com/pg/ TheNewAgeNewspaper/about/?ref=page_internal). However, doubts over the paper's credibility have grown with the recent revelations of the Gupta family's undercover operation with Bell Pottinger. Reports of its close ties to government have fuelled the suspicions. In reply to a question in Parliament in 2016, the Minister of Communications admitted that her department had sponsored a New Age breakfast briefing at a cost of one million rands and that in 2015 it had spent ten million on advertising on TNS media (News24Wire, 2017). This followed admissions that the cash-strapped public broadcaster, the South African Broadcasting Corporation (SABC), had paid TNS Media twenty million rands to broadcast the New Age breakfasts.

The SABC's Charter, framed by the Broadcasting Act No. 4 of 1999 (1999), "enshrines the journalistic, creative and programming independence of the staff of the corporation, and the constitutionally protected freedom of expression" (South African Broadcasting Act, 1999). However, it and its board has been embroiled in several controversies in recent years, which echo apartheid era disputes over censorship and political interference. In 2016, for example, 
the Chief Operating Officer provoked outrage when he banned all visual coverage of violent service delivery protests (Udeh, 2016). In 2017, the hard-hitting report from its parliamentary oversight committee led to the dissolution of the SABC Board and the dismissal of its Chief Operating Officer (Merten, 2017).

\section{LIS in democratic South Africa}

Given the threats to access to information in the young South African democracy that are discussed in the preceding sections, questions might well arise over the role of libraries are since 1994. After all, librarians often claim that libraries are crucial to democracy, calling them, for example, the "cornerstones of democracy" (American Library Association (ALA), 2001) and the "gateways to democracy" (Walker 2011). A glance at the titles given to the annual conferences of Library and Information Association of South Africa (2017) shows its attempts to promote the role of LIS in democracy and the developmental state. Thus, in 2004 the title was Libraries and Democracy: the Vital Link and in 2014 Celebrating Libraries in 20 Years of Democracy: Continuing the Dialogue.

As we argued in an earlier section, the constitutional right of access to information must imply the right of access to libraries, as the instruments of the access. Libraries play an arguably unique part in all three facets of the "informed public" that we have discussed in this paper. Thus, they mitigate information poverty; they educate people in information literacy; and they provide for the freedom of expression and information required in an open participatory democracy. However, the deteriorating position of libraries in the 1990s, as documented by several commentators (Leach 1998; Lor, 1998; Hooper and Hooper, 2000), might suggest a lack of understanding of the potential contribution of LIS to the new democracy. Evidence of the persistent under-valuing of LIS might lie in the destruction of more than 20 public libraries since 2009 in protest actions against local authorities (Lor, 2016).

Nonetheless, since the early 2000 , there have been some positive developments - like the formation of NCLIS in 2004 and the conditional grants from National Treasury from 2009 for new public library infrastructure under the stewardship of the national Department of Arts and Culture. A recent positive development late in 2016, a direct outcome of the LIS Transformation Charter which we referred to earlier, is the commissioning by NCLIS of a comprehensive policy for South African LIS to address their persistent weak standing. In a briefing to LIASA on 3 October 2017, as members of the policy research team, we summarised the problems identified in our consultations across the country. The central message was that the provision of libraries in South Africa today still reflects the racially based inequalities of the past. Thus, rural communities, especially those in the former apartheid "homelands", have inadequate public LIS; 80 per cent of schools, those serving poor black communities, have no libraries; and the historical disparities in resources across our 26 universities still exist. The policy will, we hope, resolve the long-standing divisions in the sector and address, for example, the criticism we heard from our informants of the aloofness of the libraries in publicly funded universities from the challenges facing the other subsectors. Other priorities for the policy will be professionalisation of the LIS sector, its 
urgent need for norms and standards, and stronger recognition of libraries as social hubs. In his presentation to LIASA, the leader of the policy research team, Muxe Nkondo, made a powerful case for the centrality of LIS in the knowledge economy that South Africa aspires to. He expressed the hope that the policy will be of interest to all advocates for democracy, since the aim of the policy is to empower the LIS profession in its work to build "a reading nation that is deliberative rather than divisive and permanently unequal" (Nkondo, 2017, p. 4).

The transformative drive of libraries must be considered in parallel with transformation of (other) educational institutions, in particular, the current demand that the curriculum be decolonised and that epistemologies other than Western be included. The decolonisation debate touches on knowledge production and gatekeeping decisions to valorise some voices at the expense of others', for example, in curriculum design, and also finds expression in publishing and book selection in libraries. Mbembe (2016) points out that decolonisation "is not about closing the door to European or other traditions. It is about defining clearly what the centre is" ( p. 35), and N'gugi (1981) reminds us that the centre is Africa, and not Europe ( p. 93). Thus while universities "rethink and reframe and reconstruct the curriculum" (Heleta, 2016), libraries need also to reconsider book selection policies and practices to ensure that collections are relevant and accessible in the language of their communities. Monolithic supply chain management systems in public libraries favour convenience and scale while failing to engage emerging local authors and publishers - a persistent criticism we found in our field trips to collect data for the national policy. These supply chain management systems need to be overhauled to disrupt this tendency and so meet the needs of local communities who vigorously expressed a desire to hear and read their own stories.

\section{What lies ahead for open democracy in South Africa?}

The preceding sections might indicate that disillusionment has displaced the idealism of the early 1990s. If indeed information is the "currency" of democracy, then the "toxic nexus" of politics and money (Calland, 2013b, p. 435) has sought to devalue it. The editors of the HSRC's "State of the Nation Report" in 2014 gave the dire warning: "If nothing is done to ensure efficacy, accountability and the free flow of information, and if nothing is done to protect the sovereignty of the people, South African democracy faces an uncertain future" (Meyiwa et al., 2014, p. 10).

However, our description of the threats to freedom of information and expression since the early 2000 s has, as well, demonstrated the value of Houston and Muthien's (2000) caution that the consolidation of the young democracy would require "an informed public and a vibrant civil society" (p. 64). Calling on the Constitution, civil society has indeed put to the test all the constituents of open democracy that were established in the 1990s. And they have so far passed the tests. Perhaps, the narrative of the past few years is rather one of maturing than despair. As Calland has suggested, it could be time for the "grand narrative of South African liberation" to give way to the "kind of ordinary-people-in-our-everyday-lives, bottom-up vision of democracy" (Shathley, 2013). After all, as a long-standing government minister told Calland 
in 2013: "It's too soon to give up. The stakes are too high. Too many people gave up too much for this transition" (Calland, 2013b, p. 193). 


\section{References}

Adeleke, F. (2013), "Constitutional domestication of the right of access to information in Africa: retrospect and prospects", in Diallo, F. and Calland, R. (Eds), Access to Information in Africa: Law, Culture and Practice, BRILL, Leiden and Boston, MA, pp. 83-105.

Amabhungane Centre for Investigative Journalism (2016-2017), “\#Guptaleaks", report, Amabhungane Centre for Investigative Journalism, 3 October, available at: http://amabhungane.co.za/article/20 16-09-23-two-to-tango-the-story-of-zuma-and-theguptas (accessed 27 August 2017).

American Library Association (ALA) (2001), "Democracy statement", available at: www.ala.org/ aboutala/governance/officers/past/kranich/demo/statement (accessed 2 May 2018).

ANC Youth League (2010), "Press statement: ANC youth league is fully in support of the media tribunal and rejects claims of the Press Council of South Africa", ANC Youth League, 4 August, available at: www.ancyl.org.za/docs/pr/2010/pro804.html (accessed 20 August 2017).

Barker, R. and Hawkins, K. (2015), "Recent difficulties experienced by South African journalists and newspapers”, in Reid, J., Kirsten, G. and Nkuna, J. (Eds), Submission to the Press Freedom Commission on Media Self-Regulation in South Africa, University of South Africa, Pretoria, pp. 37-43, available at: www.mediaanddemocracy.com/uploads/1/6/5/7/16577624/submission_ to_the_press_freedom_commission.pdf (accessed 24 August 2017).

BBC News (2016), "The Guptas and their links to South Africa's Jacob Zuma”, BBC News, 2 November, available at: www.bbc.com/news/world-africa-22513410 (accessed 16 August 2017).

Britz, J. (2004), "To know or not to know: a moral reflection on information poverty", Journal of Information Science, Vol. 3 No. 3, pp. 192-204.

Broadcasting Act No. 4 of 1999 (1999), available at: www.acts.co.za/briadcasting-act-of-1999 (accessed 31 August 2017).

Brummer, S. and Sole, S. (2016), "The Guptas' R51bn train grab", Times Live, 19 June, available at: www.timeslive.co.za/sunday-times/investigations/2016-06-19-the-guptasr51bn-train-grab/ (accessed 24 august 2017).

Calland, R. (2013a), "The right of access to information: the state of the art and the emerging theory of change", in Diallo, F. and Calland, R. (Eds), Access to Information in Africa: Law, Culture and Practice, BRILL, Leiden and Boston, MA, pp. 13-26.

Calland, R. (2013b), The Zuma Years: South Africa's Changing Face of Power, Zebra Press, Cape Town. Castells, M. (1998), End of Millennium, The Information Age: Economy, Society and Culture, Vol. III, Blackwell, Cambridge, MA.

Comrie, S. (2017), "R1obn in 15 days - another massive Eskom boost for the Guptas", Amabhungane Centre for Investigative Journalism, 22 April, available at: http://amabhungane.co.za/article/2017-o 4-22-r1obn-in-15-days-another-massive-eskomboost-for-the-guptas\# (accessed 27 August 2017).

Davids, Y.D. (2010), "Democratic governance versus democratic citizens: what do South Africans think?”, in Roberts, T., wa Kivulu, M. and Davids, Y.D. (Eds), South African Social Attitudes: The 2nd Report, HSRC Press, Cape Town, pp. 68-86. 
Davis, R. (2015), “TRC secret records: finally out in the open”, Daily Maverick, 31 March, available at: www. dailymaverick.co.za/article/2015-03-31-trc-secret-records-finally-out-in-theopen/\#.WaLUTZOg_os (accessed 26 August 2017).

Dick, A. (n.d.), "Librarians and readers in the apartheid struggle", Cangonet, available at: https:// cangonet.wordpress.com/articles/librarians-and-readers-in-the-south-africanstruggle/ (accessed 28 August 2017).

Dimba, M. (2014), "Freedom of information and national security in South Africa", in Meyiwa, T., Nkondo, M., Chitiga-Mabugu, M., Sithole, M. and Nyamnjoh, F. (Eds), State of the Nation 2014: South Africa 1994-2014: A Twenty Year Review, HSRC Press, Cape Town, pp. 79-92.

Electronic Communications Act 2005 (2013), "South Africa connect: creating opportunities, ensuring inclusion South Africa's broadband policy", Act No. 36 of 2005, Government Gazette No. 37119, Government notice 953, Government Printer, Cape Town, 20 November, available at: http://wiki. lib.sun.ac.za/images/c/c7/Doc-bb-policy.pdf (accessed 27 August 2017).

February, J. and Pienaar, G. (2014), "Twenty years of constitutional democracy”, in Meyiwa, T., Nkondo, M., Chitiga-Mabugu, M., Sithole, M. and Nyamnjoh, F. (Eds), State of the Nation 2014: South Africa 1994-2014: A Twenty Year Review, HSRC Press, Cape Town, pp. 25-58.

Gqirana, T. (2016), "Some NGOs are security agents of foreign forces - Mahlobo", News24, 26 April, available at: www.news24.com/SouthAfrica/News/some-ngos-are-security-agentsof-foreign-forces-mahlobo-20160426 (accessed 27 July 2017).

Gumede, W. (2011), "Delivering the democratic developmental state in South Africa", Development Planning Division Working Paper Series No.9, Midrand, Development Bank of South Africa, Midrand, available at: www.dbsa.org/EN/Aboutus/Publications/Documents/DPD\%20No\%209.\%20Delivering\%20the\%2odemocratic \%20developmental\%20state\%20in\%20South\%20 Africa.pdf (accessed 27 August 2017).

Hagg, G. and Himonga, C. (2014), "Twenty years of reconciling traditional government with modern democracy", in Meyiwa, T., Nkondo, M., Chitiga-Mabugu, M., Sithole, M. and Nyamnjoh, F. (Eds), State of the Nation 2014: South Africa 1994-2014: A Twenty Year Review, HSRC Press, Cape Town, pp. 106-128.

Harris, V. (2002), "The archival sliver: power, memory, and archives in South Africa”, Archival Science, Vol. 2 Nos 1-3, pp. 63-86, available at: www.nyu.edu/pages/classes/bkg/methods/harris.pdf (accessed 31 August 2017).

Heleta, S. (2016), "Decolonisation of higher education: dismantling epistemic violence and Eurocentrism in South Africa", Transformation in Higher Education, Vol. 1 No. 1, pp. 1-8, available at: www.thejournal.org.za/index.php/thejournal/article/view/9/31

Hooper, T. and Hooper, V. (2000), "South Africa - country report", in Issak, A. (Ed.), Public libraries in Africa: A Report and Annotated Bibliography, International Network for the Availability of Scientific Publications, Oxford, pp. 155-164.

Hope, C. (1976), "A warning to others", Index on Censorship, Vol. 5 No. 4, p. 95.

Houston, G.F. and Muthien, Y.G. (2000), "South Africa: a transformative state?", in Meyiwa, T., Nkondo, M., Chitiga-Mabugu, M., Sithole, M. and Nyamnjoh, F. (Eds), Democracy and 
Governance Review: Mandela’s Legacy 1994-1999, Human Sciences Research Council, Pretoria, pp. 37-67.

IDASA (2010), "Parliament to decide how much secrecy our democracy can permit", Polity, 20 July, available at: www.polity.org.za/article/the-protection-of-information-bill-2010-0720 (accessed 17 August 2017).

Jaggi, M. (2006), "In search of home interview with Christopher Hope", The Guardian, 26 October, available at: www.theguardian.com/books/2006/oct/21/featuresreviews.guardianreview16 (accessed 26 August 2017).

James, S.B. (2017), "Bell pottinger fires partner and apologises for 'economic emancipation' narrative for South African client", PRWeek, 6 July, available at: www.prweek.com/article/1438783/bell- pottinger-fires-partner (accessed 14 August 2017).

Jonas, N. (2016), "Media statement: statement by Deputy Minister of Finance Mr. Mcebisi Jonas (MP)", 16 March, available at: https://cdn.mg.co.za/content/documents/2016/03/16/statementbydeputyministerjonas. pdf (accessed 14 August 2017).

Kurtz, L. (2010), "The anti-apartheid struggle in South Africa, 1912-1992", available at: www.nonviolent- conflict.org/the-anti-apartheid-struggle-in-south-africa-1912-1992 (accessed 26 August 2017).

Leach, A. (1998), "An overview of the public library sector in South Africa post 1994", Innovation, Vol. 16 No. 1, pp. 3-19.

Legal veneer (2013), "South African history online", available at: www.sahistory.org.za/article/legal- veneer (accessed 31 August 2017).

Lekalake, R. (2017), "Support for democracy in South Africa declines amid rising discontent with implementation", Afrobarometer Dispatch No. 71, 9 February 2016, available at: http://afrobarometer. org/publications/ad71-south-africa-perceptions-of-democracy (accessed 9 August 2017).

Library and Information Association of South Africa (2011), "LIASA statement on the protection of information bill", available at: www.liasa.org.za/liasa-statement-on-theprotection-of- information-bill/ (accessed 15 August 2017).

Library and Information Association of South Africa (2017), "Annual LIASA conference", available at: www.liasa.org.za/liasa-annual-conference/ (accessed 10 October 2017).

Lor, P.J. (1998), "Memorandum on the state of libraries in South Africa, March", LIASA Newsletter, Vol. 2 No. 1, pp. 7-12.

Lor, P.J. (2016), "Risks and benefits of visibility: librarians navigating social and political turbulence”, Library Trends, Vol. 65 No. 2, pp. 108-127.

McKaiser, E. (2017), "Red flags of authoritarian creep", Mail \& Guardian, 21-27 July, p. 25.

McKinley, D. (2004), "The state of access to information in South Africa", research report written for the centre for the study of violence and reconciliation", available at: www.humanrightsinitiative.org/ programs/ai/rti/international/laws_papers/southafrica/McKinley\%20\%20FOI\%20in\%20South\%20Africa.pdf (accessed 14 August 2017). 
McKinley, D.T. (2017), South Africa's Corporatised Liberation: A Critical Analysis of the ANC in Power, Jacana Media, Auckland Park.

Mbembe, A. (2016), "Decolonising the university: new directions", Arts \& Humanities in Higher Education, Vol. 15 No. 1, pp. 29-45, available at: http://dx.doi.org/10.1177/4022215618513

Merrett, C. (2001), "A tale of two paradoxes: media censorship in South Africa, pre-liberation and post- apartheid", Critical Arts, Vol. 15 Nos 1-2, pp. 50-68, doi: $10.1080 / 02560240185310071$.

Merrett, C. (2004), "Voices of dissent: LIWO, civil rights and the voice of the library community of South Africa in the 1990s", Innovation, Vol. 22 No. 1, pp. 30-34.

Merten, A. (2017), "The cost of hlaudi: SABC's interim board starts to undo his damage", Daily Maverick, 10 May, available at: www.dailymaverick.co.za/article/2017-05-10-thecost-of-hlaudi- sabc-interim-board-starts-to-undo-his-damage/ (accessed 28 August 2017).

Meyiwa, T. et al. (Eds) (2014), State of the Nation 2014: South Africa 1994-2014: A Twenty Year Review, HSRC Press, Cape Town.

Mtshali, T. (2007), "Hoax emails return to haunt the ANC", IOL News, 17 March, available at: www.iol. co.za/news/politics/hoax-emails-return-to-haunt-the-anc-319256 (accessed 14 August 2017).

Muthien, Y.G. (2000), "Democratisation and accountability of the South African state", in Muthien, Y.G., Khosa, M.M. and Magubane, B. (Eds), Democracy and Governance Review: Mandela’s Legacy 1994-1999, Human Sciences Research Council, Pretoria, pp. 37-63.

National Library of South Africa (NLSA) (2016), The State of the Conditional Grant Funded Libraries in South Africa, NLSA and Department of Arts and Culture, Pretoria.

National Planning Commission (2012), National Development Plan: Vision 2030, National Planning Commission, Pretoria, available at: www.npconline.co.za/medialib/downloads/home /NPC\%20 National\%20Development\%20Plan\%20Vision\%202030\%20-lo-res.pdf (accessed 14 July 2017).

Neate, R. (2017), "Bell pottinger faces hearing over claims it stirred racial tension in South Africa”, Guardian International Edition, 13 August, available at: www.theguardian.com/world/2017/aug/ 13/bell-pottinger-pr-industry-hearing-secretsouth-africa-campaign (accessed 20 August 2017).

News24Wire (2017), "South Africa: R1 million Gupta breakfast bill for communications dept", News24Wire, 6 June, available at: http://allafrica.com/stories/201706071067.html (accessed 15 August 2017).

Ngugi, W.T.O. (1981), Decolonising the Mind: The Politics of Language in African Literature, East African Educational Publishers Ltd, Nairobi.

Nkondo, M. (2017), "The library and information services policy framework: key thrusts", paper presented at the LIASA annual conference, Johannesburg, 3 October.

Population Registration Act No. 30 of 1950 (1950), available at: www.sahistory.org.za/archive/ population-registration-act\%2C-act-no-30-of-1950 (accessed 5 May 2018).

Ranchod, R. (2016), “The quest for two thirds: the ANC's 2014 election campaign”, in Plaatjies, D. et al. (Eds),

State of the Nation. South Africa 2016: Who is in Charge?, HSRC Press, Cape Town, pp. 107-123. 
Reid, J. and Isaacs, T. (2015), Press Regulation in South Africa: An Analysis of the Press Council of South Africa, the Press Freedom Commission and Related Discourses, Media Policy and Democracy Project, Pretoria, available at: www.mediaanddemocracy.com/uploads/1/6/5/7/ 16577624/mpdp_pcsa_pfc_report2015.pdf (accessed 17 August 2017).

Right2Know (2013), "The secret state of the nation", available at: www.r2k.org.za/2013/02/17/secret- state-of-the-nation-report/ (accessed 15 August 2017).

Shathley, Q. (2013), "Richard Calland on South Africa's first 20 years of freedom”, available at: www. popmatters.com/feature/181601-first-of-generations-richard-calland-on-southafricas-first-20-years/ (accessed August 2017).

South African Communist Party (2017), "Bell Pottinger: PR support for the Gupta family", South African Communist Party, 24 January, available at: www.scribd.com/document/343530 184/Bell-Pottinger (accessed 27 August 2017).

South African Council of Churches (2017), "Report to the church public on the unburdening panel process. Regina Mundi Church, Soweto", South African Council of Churches, May 18, available at: www.methodist.org.za/sites/default/files/fileuploads/SACC Public Report on Corruption (2). pdf (accessed 14 August 2017).

State Capacity Research Project (2017), "Betrayal of the promise: how South Africa is being stolen”, available at: http://pari.org.za/wp-content/uploads/2017/05/Betrayal-of-thePromise-25052017. pdf (accessed 29 August 2017).

Statistics South Africa (2017), Poverty Trends in South Africa: An Examination of Absolute Poverty between 2006 and 2015, Statistics South Africa, Pretoria, available at: www.statssa.gov.za/publications/Report-03-10-06/Report-03-10-062015.pdf (accessed 29 August 2017).

Struwig, J., Roberts, B.J. and Gordon, S. (2016), "Amandla awethu: public attitudes, political participation and South African democracy", in Plaatjies, D., Chitiga-Mabugu, C., Hongoro, T., Meyiwa, T., Nkondo, M. and Nyamnjoh, F. (Eds), State of the Nation. South Africa 2016: Who is in Charge?, HSRC Press, Cape Town, pp. 92-106.

Talbot, C. (2004), "ANC wins South African elections in low voter turnout", World Socialist Web Site, 17 April, available at: www.wsws.org/en/articles/2004/04/safra17.html (accessed 10 August 2017).

Thamm, M. (2017), "Analysis: Bell Pottinger - more than just spin, it's political interference in sovereign states", Daily Maverick, 5 July, available at: www.dailymaverick.co.za/article/2017-0 7-05-analysis-bell-pottinger-more-than-justspin-its-political-interference-in-sovereign-states/ (accessed 10 August 2017).

The Library and Information Services (LIS) (2014), "The Library and Information Services (LIS) Transformation Charter. Commissioned by the Department of Arts and Culture (DAC) and the National Council for Library \& Information Services (NCLIS)", 7th Final ed., DAC, Pretoria, available at: www.nlsa.ac.za/Downloads_01_2014_Final_LIS_Transformation_Charter.pdf (accessed 20 August 2017).

Thloloe, J. (2017), "Op-ed: the tinkering has started against media freedom in post-apartheid SA", Daily Maverick, 11 August, available at: www.dailymaverick.co.za/article/2017- 
o8-11-op-ed-the- tinkering-has-started-against-media-freedom-in-post-apartheid-sa/ (accessed 14 August 2017).

Tlabela, K., Roodt, J. and Paterson, A. (2007), Mapping ICT Access in South Africa, HSRC Press, Cape Town.

TRC Collection (n.d.), "SAHA archive for justice", available at: www.saha.org.za/collections/trc_collections.htm (accessed 31 August 2017).

Truth and Reconciliation Commission (n.d.), "Welcome to the official TRC web site", available at: www. justice.gov.za/trc/ (accessed 28 August 2017).

Udeh, C. (2016), "SABC bans broadcast of violent protests and destruction of property", BuzzSouth Africa, available at: https://buzzsouthafrica.com/sabc-bans-broadcastof-violent- protests/ (accessed 30 August 2017).

Uncensored (2017), "Full Judgement: SANEF v Black Land First and others", Uncensored: stories that the media ignore, 8 July, available at: http://uncensoredopinion.co.za/fulljudgement-sanef-v- black-land-first-others (accessed 23 August 2017).

Walker, C.M. (Ed.) (2011), "Libraries as gateways to information and democracy improving networking, advocacy and lobbying strategies", Papers and Presentations Delivered at Six Workshops, compiled by the Goethe-Institut South Africa, Goethe Institut and IFLA, Johannesburg, April-November.

\section{Further reading}

BBC Newsnight (2017), "South Africa's Gupta scandal”, YouTube.com, 19 July, available at: https:// video.search.yahoo.com/yhs/search?fr=yhs-adk-adk_sbyhp\&hsimp=yhsadk_sbyhp\&hspart=

adk\&p= gupta $+\mathrm{BBC}+$ interviews $\# \mathrm{id}=1 \& v i d=892 \mathrm{fo} 13 \mathrm{a} 86 \mathrm{f} 228 \mathrm{a} 3 \mathrm{a} 26 \mathrm{bba} 8 \mathrm{f} 74066 \mathrm{cc}$ \&action $=$ click (accessed 8 August 2017).

Castells, M. (2004), "Informationalism, networks and the network society", in Castells, M. (Ed.), The Network Society, Edward Elgar, Northhampton, MA.

Mail \& Guardian (2016), "Guptas offered me Finance Minister position - Mcebisi Jonas", Mail \& Guardian, 16 March, available at: https://mg.co.za/article/2016-03-16-guptas-offered-mefinance- minister-position-mcebisi-jonas (accessed 16 August 2016).

National Key Points Act 102 of 1980 (1980), Government Gazette, 181(7134), Government Printer, Cape Town.

Promotion of Access to Information Act 2 of 2000 (2000), Government Gazette, 20852, Government

Printer, Cape Town, 3 February.

Protection of State Information Bill (2010), available at: www.sanef.org.za/images/uploads/b_6b_-_20

10_protection_of_state_information_1.pdf (accessed 17 August 2017).

Public Protector South Africa (2014), "When governance and ethics fail", Public Protector South Africa, Pretoria, available at: www.pprotect.org/library/investigation_report/201314/SABC\%20FINAL

\%20REPORT\%2017\%20FEBRUARY\%202014.pdf (accessed 28 August 2017). 
Public Protector South Africa (2016), “The state of capture report”, Public Protector South Africa, Pretoria, available at: www.pprotect.org/library/investigation_report/201617/State_Capture_14October2016.pdf (accessed 27 August 2017).

Snell, R. and Sabina, P. (2007), "Information flows: the real art of information management and freedom of information", Archives and Manuscripts, Vol. 35 No. 1, pp. 55-80.

South African Broadcasting Corporation (SABC) (1999), "Charter", available at: www.sabc.co.za/wps/ portal/SABC/SABCCHARTER (accessed 27 August 2017).

South African History Archive. (SAHA) (2017), "The Truth and Reconciliation Commission (TRC)", available at: www.sahistory.org.za/topic/truth-and-reconciliation-commission-trc (accessed 28 August 2017).

South African Human Rights Commission (2012), "The promotion of Access to Information Act (PAIA) and records management. Consolidated audit report 2008-2012", South African Human Rights Commission, Pretoria, available at: www.sahrc.org.za/home/21/files/Consolidated\%20PAIA\% 20Audit\%20Report\%202012.doc2.pdf (accessed 8 August 2017).

Tandwa, L. (2017), "White monopoly capital not the enemy - ANC", News24, 4 July, available at: www.news24.com/southafrica/news/white-monopoly-capital-not-the-enemyanc-20170704

(accessed 10 August 2017). 